\title{
Nowe formy wyrazowe dla tradycyjnych znaczeń leksykalnych. O wariantywności słowotwórczej i leksykalnej we współczesnej polszczyźnie (na podstawie badań ankietowych)
}

\section{Wstęp}

W naszym szkicu przedstawimy wyniki analiz przeprowadzonych na podstawie danych ankietowych. W ankiecie prosiliśmy badanych o dopisanie do podanego znaczenia realnego (reprezentowanego w słowniku przez leksem) formy językowej, która - w mniemaniu ankietowanych - miała być nośnikiem danego znaczenia (szerzej o strukturze ankiety piszemy poniżej). Naszym celem był zatem opis nowych znaków językowych dla tradycyjnych znaczeń jednostek językowych. W trakcie przeprowadzania ankiet, a i późniejsza analiza danych to potwierdziła, stało się dla nas jasne, że w proponowanych odpowiedziach widoczne jest znaczne rozchwianie pod względem zarówno formalnym, jak i semantycznym. Dlatego też obserwacji poddaliśmy konstrukcje słowotwórcze - tu widoczne jest i bogactwo wykładników formalnych, i przekraczanie granic semantycznych między kategoriami słowotwórczymi. Analizy przeprowadziliśmy też na poziomie leksykalnym, zastanawiając się nad konotacjami semantycznymi uwidocznionymi w odpowiedziach naszych ankietowanych. Na tej podstawie sformułowaliśmy hipotezy na temat standardu wiedzy potocznej u badanych osób. Ten standard widoczny jest na poziomie czysto językowym (operacje słowotwórcze i - szerzej - nazwotwórcze) oraz poznawczym - co dostrzec można w potocznej, stereotypowej kategoryzacji świata.

\subsection{Struktura ankiety}

Ankieta składa się z czterech części. W części I umieściliśmy 20 derywatów i poprosiliśmy ankietowanych o zdefiniowanie ich znaczeń. W częściach II i III wypisaliśmy po 14 znaczeń wyrazów podzielnych słowotwórczo, a w części IV 12 kolejnych znaczeń wzmocnionych cytatem, w którym wykropkowaliśmy interesującą nas formę wyrazową. W części II podawaliśmy 
znaczenia realne wyrazów, w częściach III i IV - zrekonstruowane znaczenia strukturalne. Formacje i znaczenia wyekscerpowaliśmy z USJP i z NSP 1993$-2000^{1}$ (ankietę, na podstawie której przeprowadziliśmy badania, zamieściliśmy na końcu artykułu).

Na potrzeby tego szkicu wykorzystaliśmy dane zebrane w II części ankiety, czyli tej partii, w której prosiliśmy ankietowanych o dopisanie do prezentowanych znaczeń realnych jakichkolwiek znaków językowych. Wnioski wynikające z całościowej analizy danych dostarczonych przez ankietę ogłosiliśmy w innym miejscu ${ }^{2}$; stanowią także materiał do dalszych prac analitycznych.

Badaniu ankietowemu poddaliśmy 93 osoby - studentów wszystkich roczników poznańskiej polonistyki. Ankietowani nie zawsze wypełniali wszystkie rubryki, a niekiedy wpisywali dwie lub trzy propozycje w jedną rubrykę. Konsekwencją tego jest fakt, że suma wszystkich uzyskanych propozycji dla każdego z podanych znaczeń może być różna od 93.

\subsection{Formy wyjściowe}

W analizowanej na potrzeby tego szkicu części naszej ankiety znalazło się 14 znaczeń realnych - form wyjściowych ${ }^{3}$ :

1. DUBAJKA 1. 'mieszkanka Dubaju'; 2. 'mieszkanka Dubaju - stolicy' (USJP);

2. ENERDOWIEC wyraz potoczny, o odcieniu lekceważącym 'o Niemcu mieszkającym w byłym NRD’ (USJP);

3. FACHOWOŚĆ 'biegłość w danej specjalności, dziedzinie, fachowa wiedza o danym zawodzie' (USJP);

4. GOLFISTA termin sportowy 'osoba uprawiająca grę w golfa' (USJP);

5. HEAVYMETALOWIEC wyraz środowiskowy, termin muzyczny 'przedstawiciel subkultury młodzieżowej powstałej wśród wielbicieli heavy metalu' (USJP);

6. KAPSUŁKA 1. wyraz używany w farmakologii 'opakowanie leku w proszku lub płynie, zrobione z żelatyny, najczęściej w kształcie kuleczki;

${ }^{1}$ USJP - Uniwersalny stownik języka polskiego, red. S. Dubisz, t. 1-4, Warszawa 2003; NSP - Nowe stownictwo polskie. Materiały z prasy lat 1993-2000, red. T. Smółkowa, cz. 1-4, Kraków 2004-2006.

${ }^{2}$ K. Skibski, M. Szczyszek, Semantyczne i formalne uwarunkowania serii analogicznej w najnowszej polszczyźnie, w: Studia o języku i stylu artystycznym, t. 4: Stylistyka a leksykologia: zwiazki, zależności, metody, red. nauk. K. Maćkowiak, C. Piątkowski, Zielona Góra 2008, s. 97-111.

${ }^{3}$ Przez termin forma wyjściowa rozumiemy jednostkę leksykalną, wynotowaną z opracowań leksykograficznych języka polskiego (czyli rzeczywiście istniejącą w polszczyźnie XX wieku), która jest nośnikiem określonego znaczenia. 
także: lek w takim opakowaniu'; 2. termin z zakresu fizyki, techniki 'zamknięta zasłona zabezpieczająca źródło promieniowania przed jego mechanicznym rozproszeniem' (USJP);

7. LOGOWANIE termin informatyczny 'wchodzenie do systemu komputerowego przez podanie własnego hasła umożliwiającego dostęp do systemu, a następnie rozpoczęcie w nim pracy' (USJP);

8. MAOISTA wyraz używany w politologii 'zwolennik i propagator maoizmu (doktryna i strategia komunistycznej partii Chin, sformułowana przez Mao Tse-Tunga)' (USJP);

9. MŚCIWOŚĆ wyraz książkowy 'skłonność do mszczenia się, odpłacania złem za zło, chęć, pragnienie zemsty’ (USJP);

10. NAUCZANIE wyraz książkowy 'planowa praca nauczyciela z uczniami, umożliwiająca im zdobywanie wiadomości, umiejętności i nawyków oraz rozwijanie zdolności i zainteresowań' (USJP);

11. NAWIEW termin techniczny a) 'nawiewanie, tłoczenie powietrza'; b) 'urządzenie, zespół urządzeń służących do nawiewania powietrza'; c) nawiewane powietrze' (USJP);

12. ODPLAMIACZ termin handlowy 'środek chemiczny służący do usuwania plam' (USJP);

13. TOPOGRAF termin geodezyjny 'specjalista $\mathrm{w}$ dziedzinie topografii, osoba zajmująca się sporządzaniem zdjęć terenu’ (USJP);

14. ZASILACZ termin z zakresu elektryczności 'przyrząd przetwarzający energię elektryczną z sieci lub baterii i doprowadzający ją do urządzeń elektrycznych' (USJP).

\subsection{Odpowiedzi respondentów}

Ankietowani do podanych znaczeń dopisywali warianty ${ }^{4}$ :

1. DUBAJKA $84^{5}$

- Dubajka (Dubayka) 67

- Dubajanka 9

- Dubajczanka 3

- Dubajczyk 2

${ }^{4}$ Przez termin wariant rozumiemy konstrukcję językową zaproponowaną przez ankietowanych jako odpowiedź na zadane w naszej ankiecie pytanie czy polecenie.

${ }^{5}$ Dane przedstawiono w następującym porządku: z prawej strony HASŁA podano sumę wszystkich propozycji; liczby podane przy wariantach informują o częstości ich wystapienia, co jest podstawą dla zastosowanego układu malejącego (bezpośrednio pod hasłem podano frekwencję formy wyjściowej). Jeśli kilka propozycji ma taką samą frekwencję, to układ takiej grupy jest alfabetyczny. Na końcu kolumny danego układu znajduje się informacja o niewypełnionych miejscach w ankietach $i$ ich frekwencji. 
- Dubanka 2

- mieszkanka Dubaju 1

- (BRAK) 8

2. ENERDOWIEC 85

- enerdowiec 39

- Szwab 26

- nrd-owiec 15

- szkop 3

- komunista 1

- NRDeciarz 1

- (BRAK) 10

3. FACHOWOŚĆ 86

- fachowość 24

- profesjonalizm 16

- specjalizacja 13

- specjalista 6

- fachowiec 5

- zawodowstwo 4

- mistrzostwo 2

- profesjonalność 2

- specjalność 2

- sprawność 2

- znawstwo 2

- ekspert 1

- erudycja 1

- kompetentność 1

- koryfeista zawodu 1

- rutyna 1

- spec 1

- specjalizowanie się 1

- wykształcenie 1

- (BRAK) 13

4. GOLFISTA 93

- golfista 73

- golfiarz 15

- golfowiec 4

- golfizta 1

- (BRAK) 1

5. HEAVYMETALOWIEC 98

- heavymetalowiec (Heavy Metalowiec) 45 
- metalowiec 32

- metal 17

- punk 2

- hej 1

- hevietal 1

- (BRAK) 1

6. KAPSUŁKA 93

- kapsułka 41

- kapsuła 21

- ampułka 11

- fiolka 3

- pigułka 3

- czopek 2

- globulka 2

- kauczuk 2

- żel 2

- fleczer 1

- kapsułki 1

- otoczka 1

- powleczka 1

- tabletka 1

- zawiesina 1

- (BRAK) 20

7. LOGOWANIE 93

- logowanie 75

- logowanie się 6

- loging 6

- $\operatorname{kod} 2$

- zalogowanie 2

- blogowanie 1

- enter 1

- (BRAK) 1

8. MAOISTA 78

- maoista 59

- maoizta 4

- maonista 3

- maoizmowiec 2

- komunista 1

- maoidoktrynista 1

- maoinista 1 
- maoit 1

- maoita 1

- maoizm 1

- maoizmata 1

- maojczyk 1

- maotseńczyk 1

- zwolennik Mao Tse-Tunga 1

- (BRAK) 14

9. MŚCIWOŚĆ 83

- mściwość 59

- zemsta 5

- mściciel 3

- odwet 3

- zawiść 3

- podłość 2

- złośliwość 2

- mścicielstwo 1

- mściwiec 1

- rewanżyzm 1

- wendeta 1

- zaciekłość 1

- zawziętość 1

- (BRAK) 15

10. NAUCZANIE 79

- nauczanie 25

- lekcja (lekcje) 8

- metodyka 7

- edukacja 6

- kształcenie 6

- rozkład 5

- uczenie 4

- dydaktyka 3

- nauka 3

- nauczycielstwo 2

- edukowanie 1

- kompetencje 1

- metodologia 1

- planowanie 1

- program edukacyjny 1

- przygotowanie 1 
- staż nauczycielski 1

- studiowanie 1

- zajęcia 1

- zajęcia dydaktyczne 1

- (BRAK) 18

11. NAWIEW 85

- nawiew 19

- klimatyzacja 17

- wentylacja 13

- wentylator 12

- nawiewacz 6

- dmuchawa 3

- dmuchanie 2

- nadmuch 2

- dmuch 1

- dyfuzowanie 1

- kompresja 1

- kompresor 1

- nawiewarka 1

- podmuch 1

- pompa 1

- sprężanie 1

- tłoczenie powietrza 1

- wentylowanie 1

- wiatrak 1

- (BRAK) 17

12. ODPLAMIACZ 93

- odplamiacz 71

- wybielacz 14

- acze 2

- wywabiacz 2

- detergent 1

- proszek 1

- vanish 1

- wyplamiacz 1

- (BRAK) 1

13. TOPOGRAF 92

- topograf 31

- geodeta 36

- topografista 24 
- geolog 1

- (BRAK) 2

14. ZASILACZ 81

- zasilacz 6

- transformator 27

- kabel 9

- ładowarka 8

- akumulator 5

- prądnica 4

- prostownik 3

- przetwornik 3

- przewód 3

- przedłużacz 2

- przewodnik 2

- agregator 1

- alternator 1

- katalizator 1

- kondensator 1

- łącznik 1

- prądownica 1

- prądownik 1

- wtyczka 1

- wzmacniacz 1

- (BRAK) 21

\section{Analizy}

A. Liczebność wszystkich wariantów w poszczególnych ukladach ${ }^{6}$. W 13 przypadkach - na 14 - analizowanych układów forma wyjściowa była przez ankietowanych przywoływana najczęściej. Wyjątek stanowi układ ZASILACZ, w którym formę wyjściową zaproponowano tylko sześciokrotnie, a warianty - znacznie częściej. Frekwencja słowotwórczych dubletów wobec wyjściowego derywatu mieści się między 1 wskazaniem (blogowanie, zaciekłość, maoiczyk) a 32 wskazaniami - metalowiec.

${ }^{6}$ Przez termin układ rozumiemy zestaw wariantów zaproponowanych przez ankietowanych dla danej formy wyjściowej. Synonimicznie w tym znaczeniu będziemy używali terminu struktura. 
B. Liczebność wariantów słowotwórczych w układach. Najwięcej słowotwórczych wariantów pojawiło w układzie ZASILACZ - 15: transformator, ładowarka, prqdnica, przetwornik, prostownik, przewodnik, przedtuzacz, prqdownik, pradownica, wtyczka, tacznik, alternator, wzmacniacz, kondensator, katalizator; w strukturze FACHOWOŚĆ wystąpiło 14: fachowość, profesjonalizm, specjalizacja, specjalista, fachowiec, zawodowstwo, mistrzostwo, znawstwo, sprawność, specjalność, profesjonalność, wykształcenie, specjalizowanie się, spec, kompetentność; NAWIEW ma 13 wariantów ${ }^{7}$. Najmniejszą liczbą wariantów słowotwórczych charakteryzuje się układ TOPOGRAF - 1: topografista; 2 propozycje znalazły się w strukturze ENERDOWIEC: nrd-owiec, NRDeciarz. W pozostałych wypadkach liczba wariantów słowotwórczych mieści się między 3 a 11.

\subsection{Analiza słowotwórcza}

Z danych statystycznych wynika, że ankietowani najczęściej wyzyskiwali formę wyjściową. Jednakże pojawienie się wielu wariantów słowotwórczych skutkuje rozchwianiem widocznym zarówno na poziomie słowotwórczo-formalnym (wyzyskiwanie odmiennych wykładników formalnych, czasami nowych lub nieznanych polszczyźnie), jak i na poziomie słowotwórczo-semantycznym (proponowanie przez ankietowanych derywatów należących do zupełnie innych kategorii słowotwórczych niż kategoria formy wyjściowej). Przyjrzymy się zatem tym dwóm poziomom, na których obserwowalne są wspomniane zjawiska.

\subsubsection{Struktura formalna konstrukcji słowotwórczych}

Przy każdej formie wyjściowej znajduje się kilka wariantów słowotwórczych o innej budowie słowotwórczej niż przykład wyjściowy. Z tego punktu widzenia można wyodrębnić dwie grupy:

A. Derywaty utworzone innymi wykładnikami formalnymi. Tu najbogatszą struktura jest MAOISTA - maonista, maoizmowiec, maoinista, maoizmata, maojczyk, maoidoktrynista, maoita, maotseńczyk, maoit. Znacznie mniej wariantów znajduje się w pozostałych układach, np. DUBAJKA - Dubajanka, Dubajczanka, Dubanka ${ }^{8}$.Z formalnego punktu widzenia okazuje się, że najczęstsze są tu derywaty przyrostkowe; pojawiły się też trzy złożenia (maoidoktrynista, maotseńczyk, hevietal) oraz jeden derywat przedrostkowy (zalogowanie).

7 Są to: wentylacja, wentylator, nawiewacz, dmuchawa, nadmuch, dmuchanie, podmuch, nawiewarka, kompresor, sprężanie, wentylowanie, dyfuzowanie, dmuch.

${ }^{8}$ Pozostałe układy: GOLFISTA - golfiarz, golfowiec; HEAVYMETALOWIEC - metalowiec, metal, hevietal; LOGOWANIE - logowanie się, loging, zalogowanie; TOPOGRAF - topografista. 
Często wyzyskiwano tradycyjne dla polszczyzny techniki słowotwórcze: golfowiec, zalogowanie, topografista. W jednym przypadku przywołano nowy w polszczyźnie ogólnej model słowotwórczy: login - LOGOWANIE (choć tutaj nie można wykluczyć zapożyczenia). Dość dużo neologizmów powstało za pomocą dziwacznych, utworzonych ad hoc wykładników formalnych, np.: maoizmata, maoit, Dubajczanka, Dubanka.

B. Układy, w których forma wyjściowa była zastępowana derywatami wywodzonymi od innych podstaw tymi samymi albo odmiennymi wykładnikami: FACHOWOŚĆ - profesjonalizm, specjalizacja, zawodowstwo, mistrzostwo, znawstwo, sprawność, specjalność, profesjonalność, kompetentnośc $c^{9}$. Specyficznym przykładem w tej grupie jest układ z formą wyjściową ODPLAMIACZ, w którym pojawiły się takie warianty: wybielacz, wywabiacz, wyplamiacz. Tutaj można wręcz mówić o wymianie tematów. Zatem ankietowani potraktowali tę strukturę na wzór derywatów modyfikacyjnych ${ }^{10}$. Skomplikowanym układem jest NAWIEW. Dopisywanie określonych wariantów jest zależne od interpretacji semantycznej tego derywatu (wynikającej z wieloznaczności tego leksemu), co skutkuje różną klasyfikacją kategorialną. Jeśli formę wyjściową rozumiano jako nomina actionis (NA), to proponowano następujące warianty: wentylacja, dmuchanie, sprężanie, wentylowanie, dyfuzowanie; jeśli jako nomina instrumenti (NInstr.), to: wentylator, nawiewacz, dmuchawa, nadmuch, nawiewarka, kompresor; jeśli jako nomina patientis (NPat.) - podmuch, dmuch.

W trakcie analiz okazało się, że jeśli znaczenie formy wyjściowej jest precyzyjne i daną formację można łatwo zaklasyfikować do określonej kategorii słowotwórczej, to na poziomie formalnym pojawia się wiele wariantów utworzonych za pomocą różnych wykładników słowotwórczych.

\subsubsection{Struktura semantyczna konstrukcji słowotwórczych}

Mimo że większość wariantów słowotwórczych mieści się w kategoriach słowotwórczych wyznaczonych formą wyjściowa, np.: MAOISTA - nomina attributiva (NAttr.); DUBAJKA - nomina feminativa (NFem.); LOGOWA$\mathrm{NIE}$ - NA ${ }^{11}$, to niejednokrotnie w zebranym materiale pojawiały się dowody

${ }^{9}$ Pozostałe przykłady: KAPSUŁKA - pigutka, czopek; MŚCIWOŚĆ - zawiść, złośliwość, podłość, zawziętość, zaciekłość, mścicielstwo, rewanżyzm; ZASILACZ - ładowarka, pradnica, prqdownica, przetwornik, prostownik, pradownik, alternator, kondensator, katalizator, transformator.

${ }^{10}$ Podobnie można zinterpretować strukturę: NAUCZANIE - kształcenie, uczenie, edukowanie, planowanie, przygotowanie, studiowanie.

${ }^{11}$ Stwierdzaliśmy to na podstawie prac: R. Grzegorczykowa, Zarys stowotwórstwa polskiego. Słowotwórstwo opisowe, Warszawa 1984; H. Jadacka, System słowotwórczy polszczyzny (1945-2000), Warszawa 2001. 
świadczące o rozchwianiu semantycznym na poziomie słowotwórczym (dotyczy to 9 przypadków). Polega to na tym, że ankietowani przywoływali derywat należący do zupełnie innej kategorii słowotwórczej niż forma wyjściowa. Przeważnie elementem „spajającym” formę wyjściową z wariantem było znaczenie podstawy lub podstaw, jeśli są one synonimami. Mieszano zatem kategorie słowotwórcze, nie rozumiejąc (nie dostrzegając) ich wartości kategorialnej. Dla znaczenia 'mieszkanka Dubaju' formą wyjściową i zgodną z systemem słowotwórczym jest DUBAJKA, w której miejsce zaproponowano formę błędną dubajczyk. Forma wyjściowa należy do kategorii feminatywnej, natomiast zaproponowana - do nazw mieszkańców. Podobne zjawisko zaobserwowaliśmy w wypadku znaczenia 'biegłość w danej specjalności, dziedzinie, fachowa wiedza o danym zawodzie' reprezentowanego przez FACHOWOŚĆ (nomina essendi - NE) - tu pojawiły się derywaty NAttr.: specjalista, fachowiec, spec, a także formacje z kategorii NA: wykształcenie, specjalizowanie sie $e^{12}$.

Okazało się także, że rozchwianie semantyczne może być wynikiem wieloznaczności formy wyjściowej. Tak należy zinterpretować grupę derywatów związanych z formą wyjściową NAWIEW, mającą trzy znaczenia. Można bowiem zaklasyfikować ją do: a) NA i wtedy proponowano warianty: dmuchanie, sprężanie, wentylowanie, dyfuzowanie - one też należą do NA, jednakże rozchwianie pojawia się na poziomie znaczenia jednostkowego: nie wszystkie z przytoczonych wariantów są synonimami; b) formę wyjściową można też zaklasyfikować do NInstr. - wtedy wpisywano formacje: wentylacja, wentylator, nawiewacz, dmuchawa, nadmuch, nawiewarka, kompresor - tutaj derywaty pochodzą od różnych podstaw, ale są synonimami; c) ostatnie znaczenie formy wyjściowej grupuje wokół siebie derywaty NPat.: podmuch, dmuch. Podobne zjawisko zaobserwowaliśmy w strukturze KAPSUŁKA. Derywat ten należy zaklasyfikować do deminutiwów - i tutaj wariantami są pigułka oraz czopek. Jednakże na poziomie leksykalnym wyraz KAPSUŁKA kojarzony jest z nazwami narzędzi, środków wykonania czynności (jest to jedna z form podawczych leków; por. też połączenie kapsuła ratunkowa ${ }^{13}$ ). Z tego powodu pojawiły się jako warianty derywaty otoczka, powleczka - czyste NInstr.

12 Pozostałe przykłady: MŚCIWOŚĆ (NE) - mściciel, mściwiec należące do kategorii nomina agentis (NAg.); MAOISTA (NAttr.) - maoizm (NE); NAUCZANIE (NA) - nauczycielstwo (NE).

${ }^{13}$ W USJP hasło kapsula - 1. termin lotniczy 'w samolotach naddźwiękowych: wyrzucany fotel ze szczelnie zamykającą się osłoną, w którym lotnik może się katapultować w razie awarii' - Kapsuła ratunkowa. 2. termin astronautyczny 'szczelnie zamknięty zbiornik, znajdujący się w statku kosmicznym lub sztucznym satelicie, zawierający aparaturę, zwierzęta doświadczalne itp., odłączający się od obiektu macierzystego i powracający na Ziemię po otrzymaniu odpowiedniego sygnału' ○ Kapsuła lądująca. 
Jednakże nawet i w ten sposób nie można wytłumaczyć przywołania formacji zawiesina - derywatu kategorii NPat. ${ }^{14}$.

\subsection{Wartości konotacyjne}

Interesujące przesłanki dotyczące motywacji w wyprowadzaniu nazw na podstawie danej definicji realnej uzyskać można, badając cechy niedefinicyjne wyrażone w proponowanych leksemach. Wartości konotacyjne bowiem mogą pośrednio tłumaczyć dystrybucję formantów. Sytuacja taka może opierać się na analogii w tworzeniu lub odtwarzaniu wyrazów przez użytkowników. Jednak na tym etapie badań nie można z całą pewnością stwierdzić, że analogia ta ma motywację wyłącznie semantyczną lub wyłącznie formalną. Warto jednakże wziąć pod uwagę niedefinicyjne wartości semantyczne, by podjąć próbę szczegółowego badania motywacji nazw zawartej w definicji, jak też motywacji wynikającej z analogii.

Wartość konotacyjną można rozpatrywać wówczas, gdy proponowana nazwa wykracza zakresem poza podaną definicję realną lub też wartościowanie wskazane w definicji motywuje niekoniecznie zgodne z zakresem pojęciowym propozycje nazewnicze. W pierwszym przypadku uzyskuje się zazwyczaj nazwy odnoszące się do kategorii ogólniejszych lub częściowo tylko zbieżnych znaczeniowo (swego rodzaju pozorne synonimy). W drugim zaś - są to nazwy dodatkowo motywowane aksjologicznie. Można zatem przyjąć (co zyskuje poparcie w niektórych przytoczonych niżej przykładach), że proponowane warianty to wyrazy powstałe $\mathrm{w}$ wyniku interpretacji definiendum, $\mathrm{z}$ uwzględnieniem niedefinicyjnych cech opisywanych zjawisk pozajęzykowych.

\subsubsection{Przykłady wartości konotacyjnych}

a) układ ENERDOWIEC. W przypadku tego hasła uwage skupia częsty wariant Szwab (29), a także leksemy Szkop i komunista. W pierwszym i drugim wariancie dominująca staje się wartość aksjologiczna motywowana defi-

${ }^{14}$ Ostanie dwa przykłady omawianego zjawiska. ZASILACZ - tu pojawiły się następujące formy konkurencyjne: przewodnik, przedlużacz, wtyczka, łqcznik. Dla tych wszystkich formacji rzeczywiście wspólna jest wartość kategorialna 'coś służące do wykonania czynności wskazanej w podstawie słowotwórczej'. Jednakże te podstawy nie są synonimami (nazywają zupełnie odrębne czynności). Zatem mimo dobrego zrekonstruowania ogólnego, abstrakcyjnego znaczenia kategorii słowotwórczej NInstr. ankietowani popełnili błąd wynikający z niezrozumienia znaczenia jednostkowego formy wyjściowej (czyli przytoczonego w ankiecie znaczenia realnego leksemu ZASILACZ - podobnie jak w wypadku układu NAWIEW). LOGOWANIE - tu spotykamy się z podobnym błędnym zrozumieniem znaczenia jednostkowego, co w omówionych przykładach - wpisano derywat blogowanie (tu dodatkowo pojawieniu się błędu sprzyjała podobna budowa fonologiczna obu form). 
nicją (wyraz potoczny, o odcieniu lekceważącym). Przeważa zatem wartość konotacyjna - pejoratywne określenie Niemca czy określenie „gorszego” (bo pochodzącego z NRD) Niemca. Właśnie ze względu na przewagę wartościowania proponowane warianty mają szerszy zakres, niż to określa definicja. Trzeci wariant - komunista - to przykład na specyficzny hiperonim również motywowany przede wszystkim negatywnymi konotacjami, bez względu na wymogi określone zakresem definicji;

b) układ FACHOWOŚĆ. W haśle tym występuje szereg określeń synonimicznych względem formy wyjściowej. Akcydentalnie pojawiają się warianty: rutyna czy sprawność, które mogłyby dowodzić dominacji znaczeń konotowanych;

c) układ KAPSUŁKA. Wystąpienie obok dominującej formy wyjściowej kilku alternatywnych nazw (fiolka, amputka, pigułka) może sugerować ponadto, że często przestrzeń konotacji stanowi u użytkownika języka (czytelnika definicji) konsekwencję automatycznego, uproszczonego dekodowania, w którego konsekwencji proponowana nazwa motywowana jest przez kilka pierwszych słów definicji (,opakowanie leku w proszku lub w płynie”);

d) układ MAOISTA. Także w tym przypadku pojawiło się określenie komunista jako specjalny hiperonim motywowany przede wszystkim aksjologicznie;

e) układ MŚCIWOŚĆ. Wyraźną przewagę interpretacji nad nominacją można dostrzec dzięki grupie wariantów podłość, złośliwość, zawziętość, zaciekłość. Dwa pierwsze leksemy wprowadzają wartościowanie definiowanej skłonności (mściwość jest zła), dwa kolejne zaś - charakteryzują ową skłonność, modyfikując zakres definiendum. W każdym zatem wariancie zawiera się struktura semantyczna coś jest jakieś (zamiast coś jest czymś);

f) układ NAUCZANIE. W tym wypadku obok wariantów synonimicznych pojawiają się (dość często - 8 i 6 odpowiedzi) leksemy lekcja i rozkład. Także tu można dostrzec, że dominująca wartość konotacyjna wyprowadzona z początkowej frazy definicyjnej: ,planowa praca nauczyciela z uczniami”, określiła semantykę proponowanej nazwy. Zmiana kategorii proces na zdarzenie nie znajduje uzasadnienia w definicji słownikowej;

g) układ ODPLAMIACZ. Występujące w tym przypadku nazwy własne (Ace i Vanish) także mogą stanowić nieco trywialne przykłady na motywowanie nominacji przez wartości konotowane.

\subsubsection{Sugestia strukturalna}

Mimo że analiza dotyczyła znaczeń realnych (definicji realnoznaczeniowych), to jednak można na podstawie materiału ankietowego wysunąć zasadne pytanie o wpływ na odpowiedzi respondentów zjawiska nazwanego 
dla potrzeb niniejszych rozważań sugestią strukturalną. Wyróżnienie takiego czynnika wydaje się potrzebne wówczas, gdy proponowana przez użytkownika nazwa powstaje ze względu na leksemy zawarte w definiendum (często bez ścisłej relacji zakresowej z definiensem). Dla przykładu można wskazać leksemy specjalizacja, specjalność (FACHOWOŚĆ), geodeta, topografista (TOPOGRAF) czy transformator, przetwornik (ZASILACZ). W pierwszym przypadku w definicji słownikowej występuje konstrukcja 'biegłość w specjalności', w drugim - termin topografia oraz przymiotnik geodezyjny (pełniący w definicji tylko funkcję kwalifikatora), w trzecim zaś - imiesłów 'przetwarzający' (w tym przypadku przeważyła liczba wskazań wariantu). Można by zatem (abstrahując od rozpatrywania fortunności definicji) rozważyć na tego typu przykładach strategie definiowania w słownikach ogólnych. Zagadnienie wydaje się tym bardziej ciekawe (także z leksykograficznego punktu widzenia), jeśli wziąć pod uwagę współczesną tendencję do pragmalingwistycznej redakcji haseł słownikowych.

Mając na względzie poczynione rozpoznanie problemu, warto w tym miejscu wspomnieć o kategorii potoczności w odniesieniu jednak przede wszystkim do omawianego w niniejszym szkicu materiału ankietowego.

\subsection{Potoczność}

Kategoria potoczności w języku interesuje zarówno normatywistów, jak i pragmalingwistów ${ }^{15}$. $Z$ jednej strony utrwaliło się rozumienie języka potocznego jako kategorii ekwiwalentnej wobec stylu potocznego, czyli wiązi cech językowych właściwych przede wszystkim przekazom ustnym. Takie rozumienie ma swoje poważne konsekwencje normatywne o tyle, o ile potoczność zarezerwowana jest tu dla kontaktów nieoficjalnych, prywatnych, nieraz zatem oznacza teksty znajdujące się poniżej normy językowej. Z drugiej jednak strony potoczność stanowi kategorię nadrzędna, początkowa, z której wywodzi się wszelkie inne (sublimowane) sposoby wyrażania się, inne odmiany języka (o wyższej organizacji czy konkretnej funkcji). To drugie rozumienie nobilituje potoczność o tyle, o ile jest ekwiwalentem standardu wiedzy, wspólnej podstawy percepcyjnej, stanowiącej punkt wyjścia zarówno do naukowej precyzji i specjalizacji w języku, jak i do estetyzacji i metaforyzacji literackiej.

Przywołana tu osobliwość kategorii potoczności zyskuje swoje poświadczenie także w analizowanym materiale. Chociaż jest to tylko skromna reprezen-

${ }^{15}$ Warto choćby wskazać na bardzo ciekawe opracowania dotyczące potoczności: J. Bartmiński, Styl potoczny, w: Wspótczesny język polski, red. J. Bartmiński, Lublin 2001, s. 115-134; J. Warchala, Kategoria potoczności w języku, Katowice 2003; W. Lubaś, Polskie gadanie. Podstawowe cechy i funkcje potocznej odmiany polszczyzny, Opole 2003. 
tacja, jednak można wyróżnić takie warianty proponowanych nominacji, które odsyłają do potoczności w sensie poziomu (rejestru) języka ogólnego, i takie, które poświadczają stan wiedzy (lub określone braki odpowiednich pojęć).

\subsubsection{Przykłady na potoczność jako poziom języka ogólnego}

a) układ ENERDOWIEC. Wspominany już przykład można rozpatrywać także ze względu na potoczność (motywowaną, jak wspomniano, przede wszystkim konotacyjnie). Określenia Szwab czy Szkop mają charakter potoczny (i pogardliwy), są zatem możliwe jedynie w wypowiedziach nieoficjalnych;

b) układ HEAVYMETALOWIEC. Określenia metal (częste - 17) i hej (akcydentalne, prawdopodobnie na prawach skrótu) stanowią nieoficjalne nazwy wielbicieli heavy metalu. Pojawienie się tych wariantów można dodatkowo tłumaczyć określeniem wyraz środowiskowy rozpoczynającym definicję.

\subsubsection{Przykłady na potoczność jako standard wiedzy}

Przede wszystkim należy w tym miejscu wskazać na te układy, w których pojawiły się miejsca puste, tzn. część ankietowanych nie zaproponowała żadnego wariantu dla danej formy wyjściowej. Widoczne jest to w układach: ZASILACZ (21 osób nie zaproponowało żadnego wariantu), KAPSUŁKA (20), NAUCZANIE (18), NAWIEW (17), MŚCIWOŚĆ (15), MAOISTA (14), FACHOWOŚĆ (13) i ENERDOWIEC (10). Można na tej podstawie przypuszczać, że określone pojęcia nie znajdują się w standardzie wiedzy ankietowanych użytkowników języka (nawet drogą interpretacji konotacyjnej bowiem nie został utworzony jakikolwiek wariant). Na przykładzie haseł DUBAJKA czy MAOISTA można stwierdzić, że jeśli znaczenie realne wyrażone jest za pomocą definicji o pewnych cechach informacji strukturalnej, częściej pojawiają się warianty (choć spora część z nich jest błędna). Można zatem przypuścić, że jeśli definicja słownikowa ma charakter wyłącznie pragmatyczny (mówimy tak wówczas, gdy...; mówimy o kimś/czymś, że jest... wtedy, $g d y \ldots)^{16}$, powinna dotyczyć bardzo wąsko pojętego standardu wiedzy.

Ciekawym poświadczeniem standardu wiedzy (potoczności) są propozycje nominacji w układach NAWIEW i ZASILACZ. W przypadku pierwszego z nich najczęściej pojawiał się leksem klimatyzacja (jednak zupełnie bez względu na trzecie znaczenie definicyjne - 'nawiewane powietrze'), w przypadku drugiego - były to warianty transformator (wspomniana wcześniej sugestia strukturalna), kabel i ładowarka (powszechne ,przyrządy” elektryczne).

${ }^{16} \mathrm{~W}$ ten sposób definiuje się m.in. w Innym słowniku języka polskiego, red. M. Bańko, t. 1-2, Warszawa 2000. 


\section{Wnioski}

Po przeanalizowaniu zgromadzonego materiału można sformułować kilka wniosków ogólniejszej natury.

1. Tradycyjne znaczenia, znane opracowaniom leksykograficznym, uzyskują w zgromadzonym materiale bardzo różne wykładniki formalne. Wyzyskuje się tu modele słowotwórcze odmienne od derywacyjnego typu formy wyjściowej, poszukuje się w leksykonie ewentualnych synonimów, tworzy się grupy nominalne. Wszystkie te zabiegi mają doprowadzić - w mniemaniu ankietowanych - do uzyskania wariantu równoznacznego z formą wyjściową.

2. Na poziomie słowotwórczym często dochodzi do przekraczania granicy semantycznej kategorii słowotwórczej, wyznaczonej przez derywat będący formą wyjściową. Wynika to albo z niezrozumienia znaczenia jednostkowego derywatu, albo z niezrekonstruowania wartości kategorialnej kategorii, do której należy forma wyjściowa. Natomiast analiza formalna ujawniła bogactwo wykładników słowotwórczych, za pomocą których powstawały warianty słowotwórcze (przy czym zachodzi tu taka relacja: im precyzyjniejsze znaczenie (w tym też: kategorialne) formy wyjściowej, a zatem im łatwiej ją zaklasyfikować do określonej kategorii słowotwórczej, tym większe rozchwianie formalne, czyli tym więcej proponowano nowych derywatów tworzonych wieloma wykładnikami formalnymi). Niekiedy są to formanty przypadkowo i hic et nunc „wyprodukowane”, aby utworzyć derywat, który miałby być nosicielem danego znaczenia. Na rozchwianie semantyczne i formalne wpływ mogło mieć $i$ to, że ankietowani mieli do dyspozycji tylko znaczenia realne interesujących nas wyrazów. Ten typ znaczenia nie jest tak precyzyjny i jednoznaczny, jak znaczenie strukturalne, które rekonstruowaliśmy dla innych leksemów wykorzystanych w naszej ankiecie w innych jej częściach.

3. Z powyższych analiz wynika ponadto, że jakość definicji realnoznaczeniowej istotnie wpływa na kształt leksemów proponowanych przez użytkowników języka. Definicje włączone do grupy badanych przykładów nie są jednakowo precyzyjne, co skutkuje znacznymi odchyleniami na poziomie zarówno formalnym (dystrybucja formantów i proponowane typy słowotwórcze), jak i semantycznym (interpretacja definicji z wyzyskaniem konotacji i asocjacji).

4. W sytuacjach, gdy w definicji zawarty jest leksem wartościujący, w procesie przyporządkowywania nazwy dominuje czynnik aksjologiczny nad semantycznym. Ponadto definicyjne określenia wartościujące mogą motywować poszukiwanie wariantów nazewniczych na poziomie potoczności pojmowanej jako poziom języka ogólnego. 
5. W przypadku definicji nieprecyzyjnej, skomplikowanej składniowo lub określającej mało znany desygnat występuje zjawisko sugestii strukturalnej. Użytkownik języka proponuje nazwę będącą niekoniecznie zgodnym semantycznie derywatem utworzonym od jednego ze słów zawartych $\mathrm{w}$ definiendum.

6. Warianty przyporządkowane do badanych definicji realnoznaczeniowych (znaczeń tradycyjnych) ilustrują w pewnym stopniu standard wiedzy użytkowników języka (wiedza potoczna), także wówczas, gdy użytkownik nie proponuje żadnego wariantu nazwy dla danego znaczenia. Poszerzona analiza tego zagadnienia może zatem stać się przyczynkiem do rekonstrukcji potocznego obrazu świata.

7. Obserwacje i analizy poczynione na potrzeby tego szkicu skłaniają do sformułowania ostatniej tu hipotezy: znane z opracowań leksykograficznych tradycyjne, funkcjonujące $\mathrm{w}$ „krwioobiegu” polszczyzny znaczenia albo są nierozumiane, albo błędnie interpretowane, albo nie stanowią punktu wyjścia do refleksji nad strukturą semantyczną i formalną języka polskiego. Zatem tzw. zwykli użytkownicy języka być może nie zastanawiają się nad relacją między rzeczywistością, jej intelektualną kategoryzacją i znakiem językowym będącym zwieńczeniem procesów poznawczych. Ankietowani niejednokrotnie, wykorzystując językowe przyzwyczajenia (podobieństwo brzmieniowe i pozorna tożsamość znaczenia zachodząca między formą wyjściową a wariantem), stereotypowo postrzegając rzeczywistość, wykazując bierność intelektualną, proponowali takie konstrukcje językowe, które są asocjacyjnie bądź na zasadzie automatycznej analogii związane z formą wyjściową. Stąd wynika wspomniane rozchwianie na poziomie semantycznym (słowotwórstwo, konotacje) $\mathrm{i}$ bogactwo na poziomie formalnym (wykładniki derywacji, sugestia strukturalna).

\section{ANKIETA}

1. Proszę zdefiniować znaczenie wyrazów:

\begin{tabular}{|l|l|}
\hline 1. CHYTROŚĆ & \\
\hline 2. GĄBCZASTOŚĆ & \\
\hline 3. HITLEROWIEC & \\
\hline 4. KACOWICZ & \\
\hline 5. KIBOL & \\
\hline
\end{tabular}




\begin{tabular}{|l|l|}
\hline 6. KOŁATANIE & \\
\hline 7. KRAKANIE & \\
\hline 8. LEWICOWIEC & \\
\hline 9. MALOWANIE & \\
\hline 10. OPÓŹNIACZ & \\
\hline 11. OTWIERACZ & \\
\hline 12. PARAGWAJKA & \\
\hline 13. PREZESOWANIE & \\
\hline 14. RADIOWIEC & \\
\hline 15. RAJDOWIEC & \\
\hline 16. SPRYSKIWACZ & \\
\hline 17. SPYCHACZ & \\
\hline 18. STRUKTURALISTA & \\
\hline 19. SZKATULKA & \\
\hline 20. WARCABISTA & \\
\hline
\end{tabular}

2. Do podanych znaczeń realnych proszę dopisać odpowiadające im wyrazy:

\begin{tabular}{|l|l|}
\hline 21. & 1. 'mieszkanka Dubaju’; 2. 'mieszkanka Dubaju - stolicy’ \\
\hline 22. & $\begin{array}{l}\text { wyraz potoczny, o odcieniu lekceważącym ‘o Niemcu mieszkającym } \\
\text { w byłym NRD' }\end{array}$ \\
\hline 23. & $\begin{array}{l}\text { 'biegłość w danej specjalności, dziedzinie, fachowa wiedza o danym } \\
\text { zawodzie' }\end{array}$ \\
\hline 24. & termin sportowy 'osoba uprawiająca grę w golfa' \\
\hline 25. & $\begin{array}{l}\text { wyraz środowiskowy, termin muzyczny 'przedstawiciel subkultury } \\
\text { młodzieżowej powstałej wśród wielbicieli heavy metalu' }\end{array}$ \\
\hline 26. & $\begin{array}{l}\text { 1. wyraz używany w farmakologii ‘opakowanie leku w proszku } \\
\text { lub płynie, zrobione z żelatyny, najczęściej w kształcie kuleczki; } \\
\text { także: lek w takim opakowaniu'; 2. termin z zakresu fizyki, techniki } \\
\text { 'zamknięta zasłona zabezpieczająca źródło promieniowania przed } \\
\text { jego mechanicznym rozproszeniem’ }\end{array}$ \\
\hline 27. & $\begin{array}{l}\text { termin informatyczny 'wchodzenie do systemu komputerowego } \\
\text { przez podanie własnego hasła umożliwiającego dostęp do systemu, } \\
\text { a następnie rozpoczęcie w nim pracy’ }\end{array}$ \\
\hline 28. & $\begin{array}{l}\text { wyraz używany w politologii 'zwolennik i propagator maoizmu } \\
\text { (doktryna i strategia komunistycznej partii Chin, sformułowana przez } \\
\text { Mao Tse-Tunga)' }\end{array}$ \\
\hline
\end{tabular}




\begin{tabular}{|l|l|}
\hline 29. & $\begin{array}{l}\text { wyraz książkowy 'skłonność do mszczenia się, odpłacania złem za } \\
\text { zło, chęć, pragnienie zemsty’ }\end{array}$ \\
\hline 30. & $\begin{array}{l}\text { wyraz książkowy 'planowa praca nauczyciela z uczniami, } \\
\text { umożliwiająca im zdobywanie wiadomości, umiejętności i nawyków } \\
\text { oraz rozwijanie zdolności i zainteresowań’ }\end{array}$ \\
\hline 31. & $\begin{array}{l}\text { termin techniczny a) 'nawiewanie, tłoczenie powietrza’; b) } \\
\text { 'urzadzenie, zespół urządzeń służących do nawiewania powietrza’; } \\
\text { c) 'nawiewane powietrze' }\end{array}$ \\
\hline 32. & termin handlowy ‘środek chemiczny służący do usuwania plam’ \\
\hline 33. & $\begin{array}{l}\text { termin geodezyjny 'specjalista w dziedzinie topografii, osoba } \\
\text { zajmująca się sporządzaniem zdjęć terenu’ }\end{array}$ \\
\hline 34. & $\begin{array}{l}\text { termin z zakresu elektryczności 'przyrząd przetwarzający energię } \\
\text { elektryczną z sieci lub baterii i doprowadzający ją do urządzeń } \\
\text { elektrycznych’ }\end{array}$ \\
\hline
\end{tabular}

\section{Do podanych znaczeń strukturalnych proszę dopisać odpowiadające im} wyrazy:

\begin{tabular}{|l|l|}
\hline 35. & termin historyczny 'ktoś związany z AK; członek AK' \\
\hline 36. & wyraz używany w budownictwie 'to, że się cembruje' \\
\hline 37. & wyraz środowiskowy, używany w budownictwie 'to, że się deskuje' \\
\hline 38. & $\begin{array}{l}\text { wyraz używany w politologii 'zwolennik gaullizmu (kierunek nadany } \\
\text { polityce francuskiej przez generała Charles'a de Gaulle'a)' }\end{array}$ \\
\hline 39. & wyraz potoczny 'miłośnik motocykli marki Harley' \\
\hline 40. & wyraz potoczny 'mała kajuta' \\
\hline 41. & 'bycie łatwym' \\
\hline 42. & wyraz potoczny 'właściciel ogródka działkowego' \\
\hline 43. & termin techniczny 'coś, co służy do pogłębiania' \\
\hline 44. & 'bycie starym' \\
\hline 45. & wyraz o odcieniu pejoratywnym 'ten, kto jest szczerbaty' \\
\hline 46. & wyraz książkowy 'kobieta truciciel' \\
\hline 47. & termin muzyczny 'grający na waltorni' \\
\hline 48. & \begin{tabular}{l} 
wyraz używany w farmakologii, medycynie 'coś, co służy do \\
\hline
\end{tabular} \\
\hline
\end{tabular}

4. Proszę uzupełnić puste miejsce w cytatach słowami, których znaczenie strukturalne znajduje w lewej kolumnie:

\begin{tabular}{|l|l|}
\hline $\begin{array}{l}\text { 49. wyraz potoczny } \\
\text { ‘ten, kto zajmuje się } \\
\text { alarmami’ }\end{array}$ & $\begin{array}{l}\text { „Dzwonię do dawnego właściciela. On też nie wie, co robić, jemu } \\
\text { nie wyło, ale ma numer do .................................... Dzwonię. Pan od } \\
\text { alarmu każe wsiąśc do samochodu, przekręcić kluczyk i nacisnać taki } \\
\text { pipek w dół.” / NSP 1993-2000 }\end{array}$ \\
\hline
\end{tabular}




\begin{tabular}{|c|c|}
\hline $\begin{array}{l}\text { 50. wyraz potoczny } \\
\text { 'uczestnik } \\
\text { „Baru”- programu } \\
\text { telewizyjnego' }\end{array}$ & 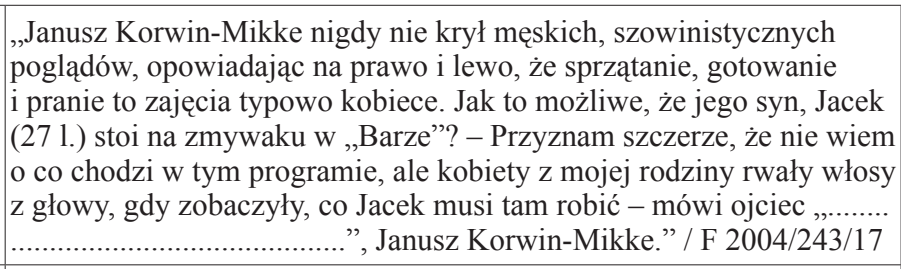 \\
\hline $\begin{array}{l}\text { 51. wyraz o odcieniu } \\
\text { pejoratywnym 'ten, } \\
\text { kto jest bogaty' }\end{array}$ & $\begin{array}{l}\text { „Młodego funkcjonariusza [policji, ubolewającego na niskie zarobki] } \\
\text { nie uważam za przypadek »kliniczny« i sądzę, że większość ludzi, } \\
\text { ochraniających biednych obywateli Rzeczpospolitej (.......................... } \\
\text { …...................... stać na prywatnych goryli!) myśli podobnie, coraz } \\
\text { bardziej olewając robotę.” / DP 1989/127/6 }\end{array}$ \\
\hline $\begin{array}{l}\text { 52. wyraz } \\
\text { środowiskowy 'bycie } \\
\text { dżokejem' }\end{array}$ & $\begin{array}{l}\text { „Chociaż, jeśli się jest dobrym, na .................................................. } \\
\text {... można całkiem nieźle zarobić. Podstawowa pensja dżokeja na } \\
\text { Służewcu wynosi około } 5 \text { milionów starych złotych miesięcznie.” / } \\
\text { NSP 1993-2000 }\end{array}$ \\
\hline $\begin{array}{l}\text { 53. wyraz o odcieniu } \\
\text { ekspresywnym } \\
\text { 'samochód marki Fiat }\end{array}$ & $\begin{array}{l}\text { "Wieczorem kiedy wracał tato do domu zabierałem jego »................... } \\
\text { / E........................ « i urzędowałem po pustych ulicach Poznania." }\end{array}$ \\
\hline $\begin{array}{l}\text { 54. wyraz potoczny } \\
\text { 'lubiący rozwiązywać } \\
\text { jolki (rodzaj } \\
\text { krzyźówki)' }\end{array}$ & $\begin{array}{l}\text { „Nie mogliśmy pozostać głusi na te żarliwe apele. Z ogromną } \\
\text { przyjemnością informujemy, że już od następnego numeru „Dużego } \\
\text { Formatu” żądania ............................................. i fanów kuchni } \\
\text { zostaną spełnione: wraca „Uczta domowa” i jolka w poziomie!” / DF } \\
\text { 2002/10/3 }\end{array}$ \\
\hline $\begin{array}{l}55 . \text { wyraz potoczny } \\
\text { 'szał na punkcie } \\
\text { Adama Małysza' }\end{array}$ & $\begin{array}{l}\text { „Wielu publicystów zauważyło, że dzisiejsza powszechna u nas ,,....... } \\
\text { p................................................” świadczy o masowym, rozpaczliwym } \\
\text { pragnieniu sukcesu. Nie ma w tym nic złego, zwłaszcza, że Adam } \\
\text { Małysz jest bohaterem zdumiewająco pozytywnym: mówi o treningu } \\
\text { i skupieniu, o owocnej współpracy w ekipie; z sympatią wyraża się } \\
\text { o rywalach.” / GW 2001/65/18 }\end{array}$ \\
\hline $\begin{array}{l}\text { 56. wyraz potoczny } \\
\text { 'zdobywca Oscara' }\end{array}$ & $\begin{array}{l}\text { „nadając tytuł Honorowego Obywatela Miasta Andrzejowi Wajdzie, } \\
\text { wysyłamy w świat ważny komunikat, że jest to fakt polityczny. } \\
\text { Andrzej Wajda nie był pierwszym polskim ................................... } \\
\text {................. ani nie jedynym. Zbigniew Rybczyński i Alan Starski } \\
\text { zdobyli Oscara za konkretne filmy. Wajda za „potęgę ducha”.” / GW } \\
\text { 2000/198/1 }\end{array}$ \\
\hline $\begin{array}{l}\text { 57. wyraz potoczny } \\
\text { 'ten, kto jest obiektem } \\
\text { transferu' }\end{array}$ & $\begin{array}{l}\text { „Wiele jednak wskazuje na to, że sytuacja przyszłych „,................. } \\
\text { …........................................” w nowych ugrupowaniach nie będzie } \\
\text { łatwa. Przykład Celińskiego, mocno kontestowanego przez znaczną } \\
\text { część działaczy SLD, pokazuje, że czasy przechodzenia „,na twarz” } \\
\text { chyba przemijają. Korzyści z nawróconych nie muszą być wcale } \\
\text { takie automatyczne; elektoraty nie zawsze się dodaja. [...] Im bliżej } \\
\text { wyborów, tym większy będzie ruch międzypartyjny. Lista transferów } \\
\text { z pewnością nie jest zamknięta.” / P 1999/35/23 }\end{array}$ \\
\hline
\end{tabular}




\begin{tabular}{|c|c|}
\hline $\begin{array}{l}\text { 58. termin techniczny } \\
\text { 'coś, co uzdatnia (np. } \\
\text { wodę)' }\end{array}$ & $\begin{array}{l}\text { „Magnetyczne uzdatnianie ciepłej wody użytkowej jest jedynym } \\
\text { sposobem dopuszczanym przez Państwowy Zakład Higieny. Poza } \\
\text { brakiem skutków ubocznych - w przeciwieństwie do np. .................. } \\
\text { …….............................. chemicznych - magnetyzery charakteryzują } \\
\text { się prostotą w montażu oraz eksploatacji, a to w naszych warunkach } \\
\text { stanowi walor niebagatelny.” / NSP 1985-1992 }\end{array}$ \\
\hline $\begin{array}{l}\text { 59. okazjonalizm } \\
\text { 'to, że się } \\
\text { wydysponowuje' }\end{array}$ & $\begin{array}{l}\text { Telefonicznie wydałem polecenie ............................................ } \\
\text { cie.......................... wszystkich sił z terenu Częstochowy (sprzętu } \\
\text { w dyspozycji' / NSP 1985-1992 }\end{array}$ \\
\hline $\begin{array}{l}\text { 60. wyraz potoczny } \\
\text { 'coś, co zakłóca (np. } \\
\text { ciszę)' }\end{array}$ & $\begin{array}{l}\text { „Szampan jest trunkiem stosunkowo nowym. Wynalazł go Dom } \\
\text { Pérignon w drugiej połowie osiemnastego wieku. Dwieście } \\
\text { pięćdziesiąt lat wystarczyło jednak, by stał się wizytówką krainy. } \\
\text { W niepamięć poszły słynne tutejsze pasztety, sery z Maroilles na } \\
\text { czele i potrawy z buraków. Mało kto przypomina sobie też dzisiaj } \\
\text { o szampańskim rzemiośle z koszykarstwem i wyrobem instrumentów } \\
\text { na czele. Pośród przedmiotów wydających dźwięki specjalizuje się } \\
\text { region w ..................................................................... ciszy - dętych. } \\
\text { Mało kto wie, że sam wielki Louis Armstrong grał często na trąbkach } \\
\text { zrobionych w departamencie Aisne.” / P 2000/29/38 }\end{array}$ \\
\hline
\end{tabular}

\section{Krzysztof Skibski, Michał Szczyszek}

\section{New Word Forms of Traditional Lexical Meanings. On Word-formative and Lexical Variation in Modern Polish (on the basis of questionnaires)}

The article presents the results of the analyses of the material collected by means of questionnaires, in which the informants are asked to complete a specific meaning of a real lexeme (excerpted from the lexicographical studies into modern Polish) with a linguistic form, which - in the opinion of the respondents - is supposed to be a carrier of a particular meaning. Our aim has been to describe new language signs for traditional meanings of linguistic units. Word-formative structures underwent observation; the analyses were also conducted on the lexical level by probing into the semantic connotations revealed in the answers of the informants.

In the answers proposed by the respondents one can notice a marked divergence with regard to both form and semantics. On the level of word formation, the proposals of the respondents often go beyond the semantic boundary-defined by a derivative being an original form - of word formation category. Word-formative formal analysis revealed a multitude of elements by means of which these word formation variants were created (there exists a relationship: the more precise the meaning of the original form, the more word formation variants). Moreover, the lexical analysis demonstrated that the semantic divergence of variants was influenced by the fact that the respondents disposed only of the real meanings of the original forms. The respondents sometimes made an attempt (not very successful) at interpretation of the original definition, taking advantage of, for example, the phenomenon of connotation and association: when an evaluating lexeme appeared in a definition, in the process of categorizing variants 
there dominated an axiological factor over the semantic one. Additionally, it has been observed that in the case of an imprecise or syntactically complex definition or the one determining a poorly known designate, the phenomenon of structural suggestion is observed: a language user proposed a variant derived from one of the words included in definiendum. The completed observations allow scholars to formulate the following hypothesis: the traditional meanings, known from lexicographical studies, are either not understood or mistakenly interpreted, or, cannot be seen as a point of departure for the study of the semantic and formal structure of the Polish language. Thus, the so-called ordinary users of language may not think about the relationship between reality and its intellectual categorization and a linguistic sign being the culmination of a cognitive processes, and this, in turn, illustrates the standard of their knowledge- a common knowledge. 